\title{
COOPERATION AND MUTUAL RELATIONSHIPS OF CITIES AND THEIR HINTERLANDS WITH REGARD TO THE OPERATION OF EU INTEGRATED DEVELOPMENT INSTRUMENTS*
}

\author{
Jan Binek ${ }^{1}$, ZdeněK OpraviL ${ }^{2}$, Roman Chmelař ${ }^{1}$, Hana Svobodova ${ }^{1}$ \\ ${ }^{1}$ GaREP Ltd., Company for Regional Economic Consulting, Brno, Czech Republic \\ ${ }^{2}$ Department of Human Geography and Regional Development, Faculty of Science, University of Ostrava, \\ Ostrava, Czech Republic
}

Manuscript received: January 27, 2015

Revised version: March 21, 2016

Binek J., Opravil Z., Chmelař Z., Svobodova H., 2016. Cooperation and mutual relationships of cities and their hinterlands with regard to the operation of EU integrated development instruments. Quaestiones Geographicae 35(2), Bogucki Wydawnictwo Naukowe, Poznań, pp. 59-69, 4 figs.

AвsтRACт: This paper deals with the institutional and factual readiness of cities and villages in the Czech Republic to use Integrated Territorial Investments (ITI). On the basis of a questionnaire survey carried out in May 2014 among representatives of 69 municipalities around the core cities of Brno, Jihlava, Olomouc and Hradec Králové - Pardubice as well as a comparison of several model agglomerations, it identifies the main problems and proposes solutions to them. The main theme of this paper is to evaluate the formation of partnerships of municipalities and the process of creating integrated strategies for metropolitan areas. The paper also deals with the relationships and functional links between cities and villages and their hinterland, the common development issues and the existing structures of cooperation and communication. In the conclusion possible recommendations are given to improve the ITI functioning in the Czech Republic on the basis of both, the assessment of the situation in the Republic itself and the reflection on developments in other EU countries.

KEY WORDS: integrating instruments, Integrated Territorial Investments, development of cities, hinterlands of cities, Czech Republic

${ }^{1}$ GaREP Ltd., Company for Regional Economic Consulting, Náměstí 28. Řijna 3, 60200 Brno: e-mail: garep@garep.cz

${ }^{2}$ Department of Human Geography and Regional Development, Faculty of Science, University of Ostrava, 30. Dubna 22, 70103

Ostrava:e-mail:z.opravil@seznam.cz

\section{Introduction}

The EU 2014-2020 programming period brings some new challenges. Besides an increased emphasis on the conceptual coherence of intervention, it also strengthens territorial dimensions. In this context, it establishes the Regulation no.
1303/2013 of the European Parliament and the Council laying down common provisions on the European Structural and Investment Funds and introduces new integrated tools: CommunityLed Local Development (CLLD) and Integrated Territorial Investment (ITI). Community-Led Local Development is a process whereby local

* This paper was prepared as part of the research project TD020018: Mechanisms of Cooperation between Cities and Municipalities in Relation to the New Integrated Approaches of the EU, with the financial support of the Technology Agency of the Czech Republic. OPEN 
stakeholders develop responses to particular challenges faced within their communities. It is carried out through integrated and multi-sectoral area-based local development strategies, and takes into consideration local needs and potential, includes innovative features in the local context, networking and, where appropriate, co-operation. In the Czech Republic the CLLD is used in rural areas.

Also ITI is a tool to implement territorial strategies in an integrated way. In principle, the Integrated Territorial Investments are applicable to different types of territories but in most EU countries are primarily directed to the development of the urban regions. The main idea in this concept is the concept of the relation between a city and its hinterland and the development of the whole territory as a functioning unit.

In addition to those processes, urban development has been an increasingly important issue in the recent decade. In the course of the Dutch EU presidency in the second half of 2004, at an informal meeting, the ministers for territorial planning and regional development approved the Urban Acquis, which summarises the main principles of a comprehensive approach to urban policy. Rotterdam 2004 conclusions included - in addition to the Urban Acquis - recommendations for the implementation of the urban policy agenda at the national level with respect to the Lisbon and Gothenburg Agenda, Knowledge-based Economy, Social Incorporation and Relationships of a City vs. Region. Another significant document dealing with the principles and development of urban policy is the Leipzig Charter on Sustainable European Cities, which was approved at the meeting of the EU Member States Ministers on $24^{\text {th }}$ and $25^{\text {th }}$ May 2007 in Leipzig. The Ministers also made there a commitment to apply the principle of integrated urban development and to create an adequate factual and administrative framework for its implementation at national levels. The conclusions and recommendations of the Leipzig Charter emphasise two issues: (1) a broader use of integrated approaches to urban development policy, including the creation of an appropriate framework for this purpose at national levels; (2) a focus on disadvantaged areas, districts in the context of a city as a whole.
The Czech Republic will use the Integrated Territorial Investment (Integrované územní investice) for the development of the urban regions (areas) in 2014-2020. It will also benefit from the Integrated Area Development Plan (IADP, Integrovaný plán rozvoje území, IPRÚ) as a specific Czech tool. It is assigned to the urban areas of regional importance. The framework document guiding activities in urban development and responding to the EU urban policy is a conceptual document called Principles of the Urban Policy.

The basis for the application of the integrating tools mentioned above is a functional partnership between cities and neighbouring villages. Urban development is affected by processes going outside the limits of cities, in their hinterlands; and many processes taking place in cities are important to municipalities in the hinterland. The paper focuses on the evaluation of the conditions of cities and municipalities in the Czech Republic for the implementation of Integrated Territorial Investment, and the Integrated Area Development Plan. It mainly concerns the question of forming common interests and projects, willingness and ability to cooperate.

There are, however, important differences between an ITI and CLLD. CLLD is a strictly bottom-up approach. It is a local action group that determines the content of the local development strategy and operations financed under it. The ITI, on the other hand, does not prejudge how decisions are taken on investments themselves: this process may be top-down or bottom-up, or a combination of the two. As such, CLLD could, for example, be one component of an integrated urban strategy implemented through an ITI (Integrated Territorial Investment - Europe, 2014).

Based on previous findings, the research is strengthened by several research hypotheses:

(H1) core cities (i.e. centres of agglomerations) and the hinterland cooperate minimally, it is usually bilateral and purpose-oriented cooperation (not comprehensive cooperation);

(H2) joint projects are quite difficult for municipalities to imagine, with the exception of infrastructural projects; and

(H3) municipalities in the hinterland of cities expect some benefits from the instruments of the ITI and IADP directly to the given municipality. 
The hypotheses were verified/tested using a field research on views of representatives of five core cities (Brno, Hradec Králové, Jihlava, Olomouc, Pardubice) and 69 municipalities in their hinterlands (13 municipalities from the hinterland of one city on average). The research was conducted in May 2014 when the basic information about the integrated development instruments was known. Structured interviews were used when inquiring the respondents. The questionnaire for representatives included 16 open questions. The answers were evaluated in a qualitative way by an analysis of key words.

\section{Approaches to the development of cities in the EU context}

The issue of development, particularly regional development, has come to the fore in the Czech Republic, since the 1990s especially.

The experience with regional policy, or previous results of regional surveys, were very limited in the Czech Republic compared with other countries in Western or Central Europe (e.g. Poland, Hungary). The increased interest in regional development arose due to significant differences, e.g. in the unemployment rates, average wages and salaries, or interest of local and regional entities in processing strategic documents. The Czech Republic's accession to the European structures also increased the awareness of the modern concept of regional policy promoted by the EU.

The basis for the concept of an appropriate regional policy but also for the preparation of lo$\mathrm{cal}$ and regional strategies, is the knowledge of current theories of regional development. There are many regional development theories and they represent systems explaining the operation of fundamental factors, entities, mechanisms and other regional development relations in a context. The purpose of regional development theories should be to assess the hierarchy of frameworks, trends, to identify and track mechanisms and regional development processes, and to understand the role of main actors and their degree of autonomy, including their relationships and positions (Blažek 1993, 1996, Blažek, Uhlíř 2011, Wokoun, Malinovský et al. 2008).

According to the economic trend that was the main source for the relevant regional development theories, we can divide those theories into neoclassical, Keynesian, neo-Marxist, neo-liberal, and institutional ones. At the same time, the theory of each trend tries to answer the question of the role of the state in the economy. The aim of the theoretical part is to identify the various theories of different trends which in their essence and content emphasise the significance of partnership and cooperation between subjects in urban regions or agglomerations. The presented overview describes the development of regional theories rather than concentrating on or accentuating the trends emphasising the significance of partnerships and cooperation.

What Richardson (1979) considers predecessors of regional development theories are location theories that study the relationship of economic activities and the spatial distribution of the economy. A paper by von Thünen $(1826,1966)$ is considered to be the top of the earliest works explaining the location of individual economic activities; the paper focuses on regularities in the distribution of types of agricultural activity. In the location theory, we can distinguish four basic trends of neoclassical theories of location. The first one, represented by Weber $(1904,1928)$, deals with the explanation of location decisions of companies where the location factors were defined in the framework. Weber also introduced the concept of agglomeration economies. The second trend was to investigate the interdependence of location decisions of different companies competing for market space (Blažek, Uhlír 2011). The third trend is based on a behavioural paradigm (e.g. Wolpert 1970) and it highlights primarily soft factors of perception, decision-making and location. The fourth trend of location theories tries to explain the spatial organisation of the economy as a whole. The most important is Christaller's theory (1966) of central places, which is based on works by von Thünen $(1826,1966)$ and Weber $(1904,1928)$. The theory tries to "clarify the nature of fundamental regularities in the structure and functioning of the residential system".

Christaller's theory was developed by August Lösch $(1944,1954)$. Weber and Lösch were followed by Isard, who tried to link economics, geography and spatial planning (Isard 1960). His aim was to transform descriptive regional economics into an exact and theoretically advanced science (Wokoun, Malinovský et al. 2008). Schoenberger 
(1989) claims that the weak point of the location theory is that location is only one component of company strategies.

Holland (1976) rejects the neo-classical theories for their unrealistic assumptions. The author sees the cause of regional problems in an unequal distribution of economic power in society. The key subjects are big companies that create a particular sector of the economy - mesoeconomics. Only large companies can finance the research and development, and implement innovations. Thus, there is an uneven contest between small and large companies. The author considers a decline in intra-regional trade barriers as an impulse for the dominance of large companies. He suggests a solution to this problem in strengthening the regulatory role of the state, strengthening trade unions, and adopting of the legislation regulating location decisions intended to make large companies locate their branches in regions lagging behind. Vernon (1966), however, comes up with the idea that the inequality of regions is due to the production of particular products depending on their life cycles. The prosperity and standards of living in regions may depend on strategies of large companies (Markusen 1985), which seek to make a profit, and the strategy itself is different at various stages of profitable cycles.

The core-periphery theory, by contrast, considers regional growth to be an imbalanced process; it distinguishes the importance of export industries for economic growth and emphasises the role of demand in its stimulation. In the 1950s, two theoretical trends emerged, one of them being the growth poles theory formulated by Perroux (1950) and Boudeville (1966). Uneven development is taken for granted because the growth cannot occur everywhere equally. A new concept of growth pole theory was introduced. The poles are points (places) in time and space supporting growth. The driving industry in the region is defined as a rapidly expanding industry with big and innovating companies. Thus, as the region develops, it sends impulses to its surroundings, which we can call the 'driven industry'. The principle of polarisation and the attraction of some economic activities lead to the region's improved economic performance (Wokoun, Malinovský et al. 2008).

There are crisis periods in the economy and society, and these periods are overcome by adapting structures and forms that ensure a relatively long period of growth and stability (Lipietz 1986, Aglietta 1979). The term of 'accumulation' refers to long-term growth and stability. The ideas of a regulation theory, which originated in France in the 1970s, correlate the way of division of the created social product and the character of politics and the organisation of society. This is called a 'regulation', which allows the reproduction of the mode of accumulation and adaption of conflicting interests and the behaviour of individual subjects (Blažek, Uhlír 2011).

New economic geography brings agglomeration benefits or various mathematical models of external savings into its research field (Krugman 1991, 1994, Fujita, Krugman 2004, Ottaviano, Thisse 2005). Some part of a geographical village welcomed the new trend very much and considered it a very promising start of cooperation between geographers and economists; other geographers were more sceptical (Martin 1999, Sheppard 2001). They referred to very highly sophisticated mathematical methods that can be applied only to quantifiable matters. The sceptics also pointed out that those theories did not deal with, e.g., the role of local institutions, the inflow and outflow of foreign investments in the political, cultural or social integration of regions.

An important chapter in regional development theories is one based on an institutional approach. They are useful in explaining the origin and development of differences and mechanisms of evolutionary changes in the economy between the state and regions (Wokoun, Malinovský et al. 2008). Nelson (1988) states that in the traditional concept of mainstream economics there are three areas to which the economy did not pay enough attention. One is innovations, new technologies and the learning process; the second concerns the functioning of companies; and the third includes institutions. This theoretical trend is characterised by a distrust of large, general theories, puts more emphasis on the uniqueness of institutions, and gives room to an individual choice of the actor, even on the basis of subjective reality. This group includes, e.g., the theory of manufacturing districts. The authors are Italian economists Bagnasco (1977), Becattini (1978) and Brusco (1982), who analysed the organisation of production in the region of the so-called 'third Italy'. The origin of this name is attributed to Bagnasco; it 
denotes the area of the developed north of Italy, the economic success of which is not based on the prosperity of big companies, but on small, cooperating companies. The basis for growth in the region was the maximum utilisation of all advantages/benefits coming from spatial proximity and similarity (Blažek, Uhlîř 2011).

Another element of the institutional theory is the cooperation of local and regional actors based on mutual trust. Each actor is involved in some network the quality of which is largely influenced by its capabilities. From the viewpoint of prospects and chances of the actors, it depends on the intensity of their involvement in the networks, but also on the content that the networks communicate.

It is also necessary to implement the principle of subsidiarity and local responsibility for effective regional development. This set of theories of regional development is connected with the discussion on localities which took place in the 1980s in Great Britain. It concerned a research project of the transformations of residences/places and regions. The project was led by Philip Cooke and it concerned a dispute of how far a locality could be affected by its inhabitants and other regional bodies. Seven localities were studied in Great Britain, both growing and declining. Cooke (1989) sees a locality as a space where an active participation of the population can be manifested in the effort to promote their interests. Their greater involvement might be a way to economic prosperity. The main contribution of this study is a refusal to create a universally valid theory of regional development.

In Europe, various forms of integrated instruments have been applied for several decades. The idea of integrated instruments was demonstrated by Myrdal (1957). What Myrdal considers a basic tool to overcome backwardness is an Integrated Development Plan that will enable the implementation of socially beneficial investment projects. These actions are themselves non-profit and achieve external economies and other elements to boost growth. From today's point of view, the integrated instruments are the most important development in about the last twenty years, when the European funds were set up in their current form.

\section{The EU 2014-2020 programming period and integrated territorial investments}

The Czech Republic also emphasises the EU 2014-2020 programming period of integrity and territorial targeting of individual future investments that will be supported through the European Structural and Investment Funds. Two new integrating tools (CLLD, ITI) have been created for this purpose to help improve the effects of the EU subsidy policy. The basic definition of both instruments listed in Regulation no. 1303/2013 of the European Parliament and the Council on Common Regulations of the European Structural and Investment Funds is general and does not oblige the member states to any specific use.

For example, the implementation of the ITI into national structures is not considered in the United Kingdom at all, because the existing organisational structure fully allows the financing of multi-fund investments within the framework of the European Regional Development Fund (ERDF), the European Social Fund (ESF) and the European Agricultural Fund for Rural Development (EAFRD). There is no interest in the ITI tool in Wales and Gibraltar; they do not consider it due to their sizes. In contrast, Scotland is planning to use the ITI for its socio-economic needs in two areas (Partnership Agreement United Kingdom 2014: 4-5). The ITI tool will not probably be used in Ireland, because the local government has not found any sufficient space for its use considering its operational programmes (Partnership Agreement Ireland 2014: 189). The German federative states of BadenWürttemberg and Schleswig-Holstein count on using the ITI; there it should be financed by the ERDF. In other federative states, urban development is solved through integrated urban development plans without the use of the ITI (Partnership Agreement Germany 2014: 220).

The introduction of the ITI tool is not planned in Austria either. Cities are seen as centres of development, and all activities related to research and technological development, the fight against poverty, and issues concerning transport will be supported here. Urban development is expected to get at least 5\% of the ERDF and IWB (Investitionen in Wachstum und Beschäftigung). 
These grants are mainly to increase the programmes in Vienna, Upper Austria and Styria. The themes of cities are then reflected in various national programmes, a special emphasis being on strategies of smart cities, mobility, sustainable urban development, and social affairs against segregation (Partnership Agreement Austria; 2013: 57-61).

The Spanish want to use the ITI in conurbations located in rural and fishing areas where the population exceeds 300,000 . In conurbations, they want to continue the URBANA project, which was implemented in the 2007-2013 period. The projects in urban areas should be financed mainly from the ERDF and ESF (Partnership Agreement Spain 2014: 336-348).

The situation in the Slovak Republic is similar to the Czech Republic. The basic requirement for the implementation of the ITI is the existence of a strategic document that defines overall goals, including the expected results, relevant territories, investment priorities, and the implementation of strategies, together with the corresponding monitoring mechanism. In Slovakia, the document required for the implementation of an integrated territorial investment is called a Regional Integrated Territorial Strategy (RITS). Regional integrated territorial strategies are prepared at the level of self-governing regions (8). They contain an integrated strategy of sustainable urban development. A self-governing region (the authority for RITS coordination) ensures the preparation and implementation of RITS in accordance with the principle of partnership, whereas regional centres, i.e. seats of local self-governments (coordinating bodies for sustainable urban development) are responsible for the preparation and implementation of the integrated territorial strategy of the urban area, also in accordance with the principle of partnership. In all, regional self-governments in Slovakia are planning to draw $6.5 \%$ (i.e. almost 1 billion EUR) of the total ERDF resources allocated to the country for the 2014-2020 programming period. The ERDF funds within the Integrated Regional Operational Programme (IROP) will be used for the ITI. The planned measures will additionally be supported by 'soft' measures funded through the ESF Operational Programme for Human Resources to ensure an integrated and comprehensive nature of the solutions (Partnership Agreement Slovakia 2014: 272-274).

The ITI in Poland is known as ZIT (Zintegrowane Inwestycje Terytorialne). The ZIT will be compulsory in provincial cities and regions that are functionally linked to them. The ZIT represents one of the key roles described in the OSI document (obszary strategicznej interwencji państwa). The ZIT in provincial towns and related areas will be funded through a mandatory allocation from the ERDF and EFS through regional operational programmes. For this purpose, at least $5.2 \%$ of the ERDF and $2.4 \%$ of the ESF will be set aside. In addition to the regional operational programmes, there will be another source of the support for the ZIT strategy in the provincial towns and their related functional areas - POIiŚ 2014-2020 (Program Operacyjny Infrastruktura i Środowisko) and POPW 2014-2020 (Program Operacyjny Polska Wschodnia) - which should serve as a source of support for selected projects within the ZIT strategy agreed between the European Union and the related IZ (Instytucja zarządzająca) (Partnership Agreement Poland 2014: 213-216).

In Slovenia, the ITI is intended to be used to implement integrated actions for sustainable urban development in towns with over 20,000 inhabitants. The main themes of integrated urban development projects include the quality of the environment, urban security, energy efficiency, transport accessibility, the development of creative industries, and the development of business environment and social inclusion. Slovenia used $6.19 \%$ of its allocated total ERDF, which means $€ 86,105,165$, for the integrated project involving the sustainable development of the country. The total amount allocated from the ESF has not been defined yet. Some projects, however, count on funding from the ESF (Partnership Agreement Slovenia 2014: 147-154).

The approach of the analysed countries to the use of ITI is specific. Among the decisive factors for the use or non-use of integrated tools are, in particular, experience in implementing similar instruments from the previous period (e.g. sustainable urban development) and settlement (city division $x$ countryside) and the administrative structure of the individual countries. The ITI benefit is a general definition at the central level and individual requirements of funding under the 
terms of individual countries. Thanks to the principle of subsidiarity, it is possible to target subsidies directly to the main problems of regions, thereby increasing the efficiency of the funds expected. Most of the surveyed countries where multi-fund financing is not possible yet, welcome these tools. Their great universality and the inability of individual countries to create a functional organisational structure can be a problem.
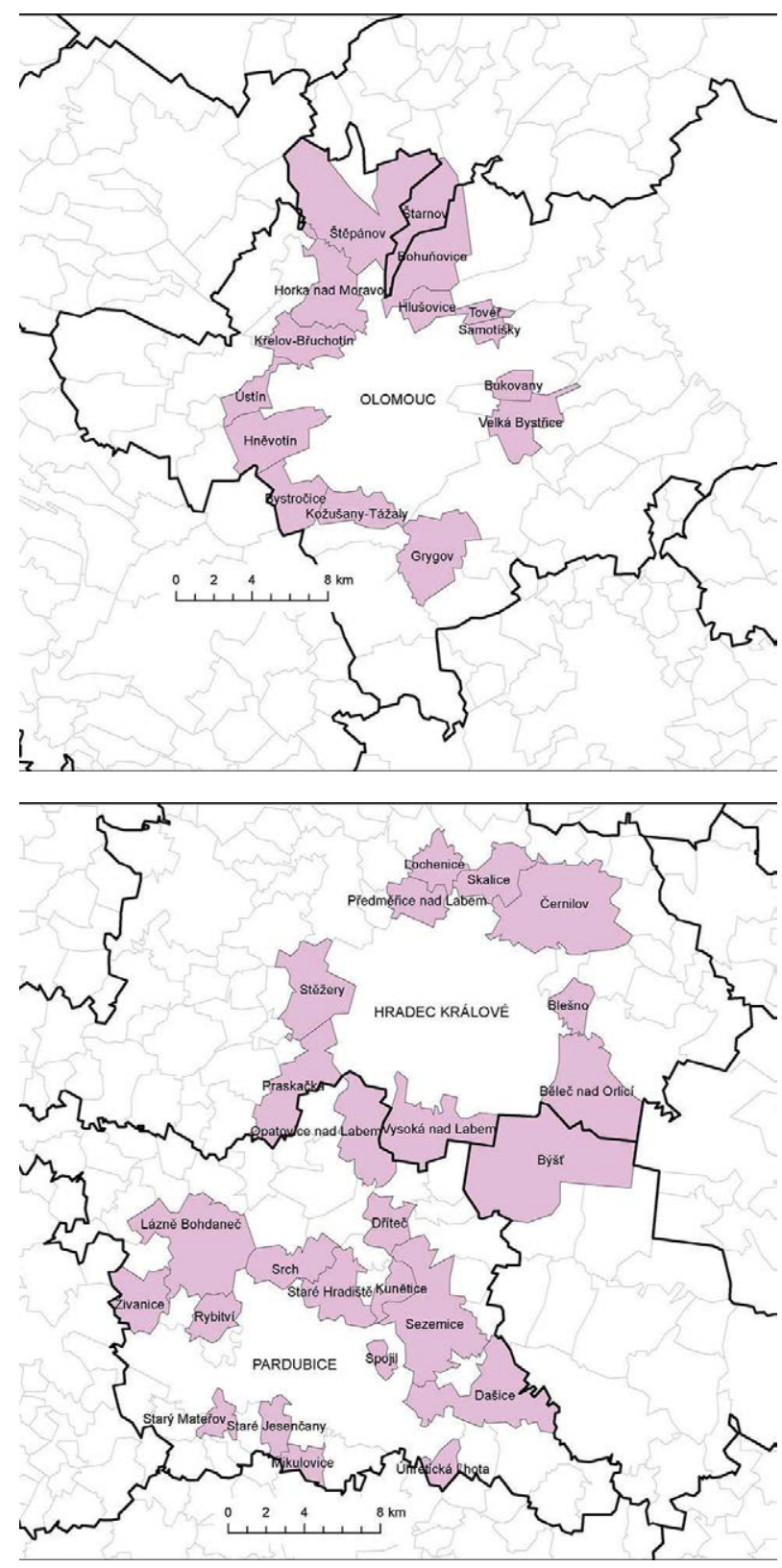

\section{Integrated territorial investments in the Czech Republic}

The implementation of integrating tools is very difficult, both for core cities and especially for the communities around them for which this approach is new in fact. The Czech Republic implemented projects within integrated urban development plans in the 2007-2020 programming period. However, they were put into effect only in a core city and only rarely more subjects cooperated in this matter. The concept of integrating tools
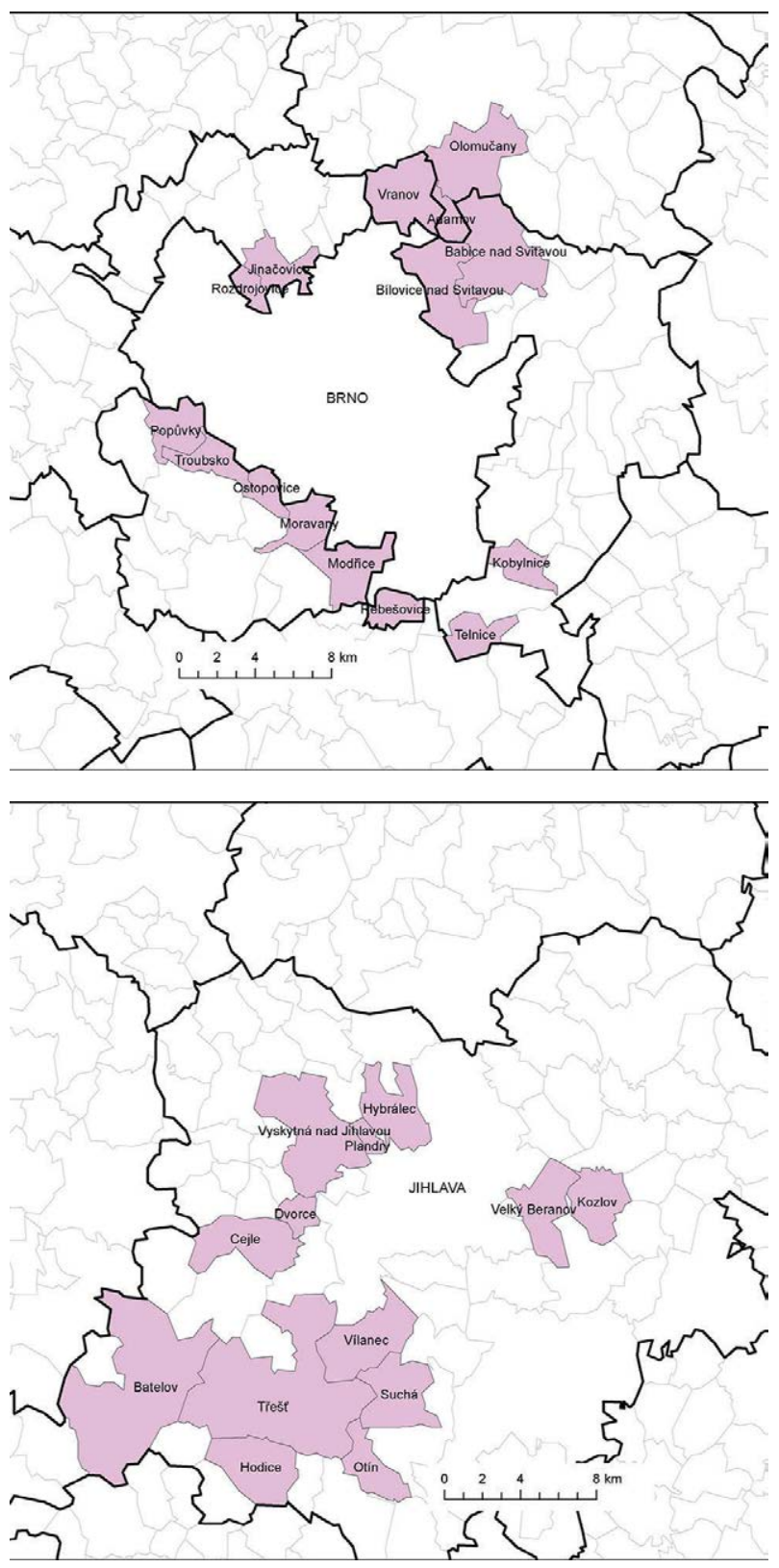

Fig. 1. Municipalities in the hinterlands of the core cities participating in the survey. Source: Survey in the municipalities in the hinterlands of core cities, GaREP, 2014. 
is much more complex. Thematically it is possible to solve a wider range of problems, too. These are defined for each territory - an agglomeration or a local group - in accordance with guidelines set up in their strategies. So, local action groups (LAGs) cope with the introduction of integrated approaches in the easiest way; it is due to their experience with the LEADER method in the past.

The problems with the introduction of new integrated approaches are not, however, based only on their novelty, but especially on the ambiguity of some formal and informal processes. Interviews with representatives of core cities, villages in their hinterlands and LAGs revealed many problems and uncertainties connected with the implementation of integrated approaches.

One of the issues lies in communication. Political leaders of major cities communicate insufficiently with communities in the hinterland, the communication therefore occurs very often at the level of officials and clerks, but the preparation of the ITI/IADP is the responsibility of the mayors or their deputies. The core cities also communicate more with larger municipalities because they have in fact nothing to offer except facilities for recreation and leisure activities. The core cities, in turn, feel the load of municipalities in the hinterland, particularly the high number of people commuting daily to a city, which puts very high demands on all the infrastructure and services whose operations are not supported by the municipalities. Small municipalities are not interested in cooperation with the core cities; there is often absence of themes for this cooperation. Their worries are usually that those cities will set the ITI/IADP to suit their own goals, and the municipalities in the hinterland will not be able to use them adequately for themselves. The proximity of core cities means particular benefits in terms of job opportunities. Another advantage is the availability of public services as well as cultural and sports activities. On the other hand, the burden of towns situated near core cities is the volume of traffic and the related pollution. Another is the immigration of people from cities to nearby villages. Immigration is a factor that can be viewed positively or negatively, although negative experience predominates. The intensive immigration of new residents is related to other aspects that affect the life of the communities, e.g. higher prices of real estates, overcrowded schools, lack of interest in the activities in municipalities, or a decline in social and cultural life there.

The unwillingness of smaller municipalities to support or cooperate on larger projects of cities lies in the fact that they do not see the benefits of

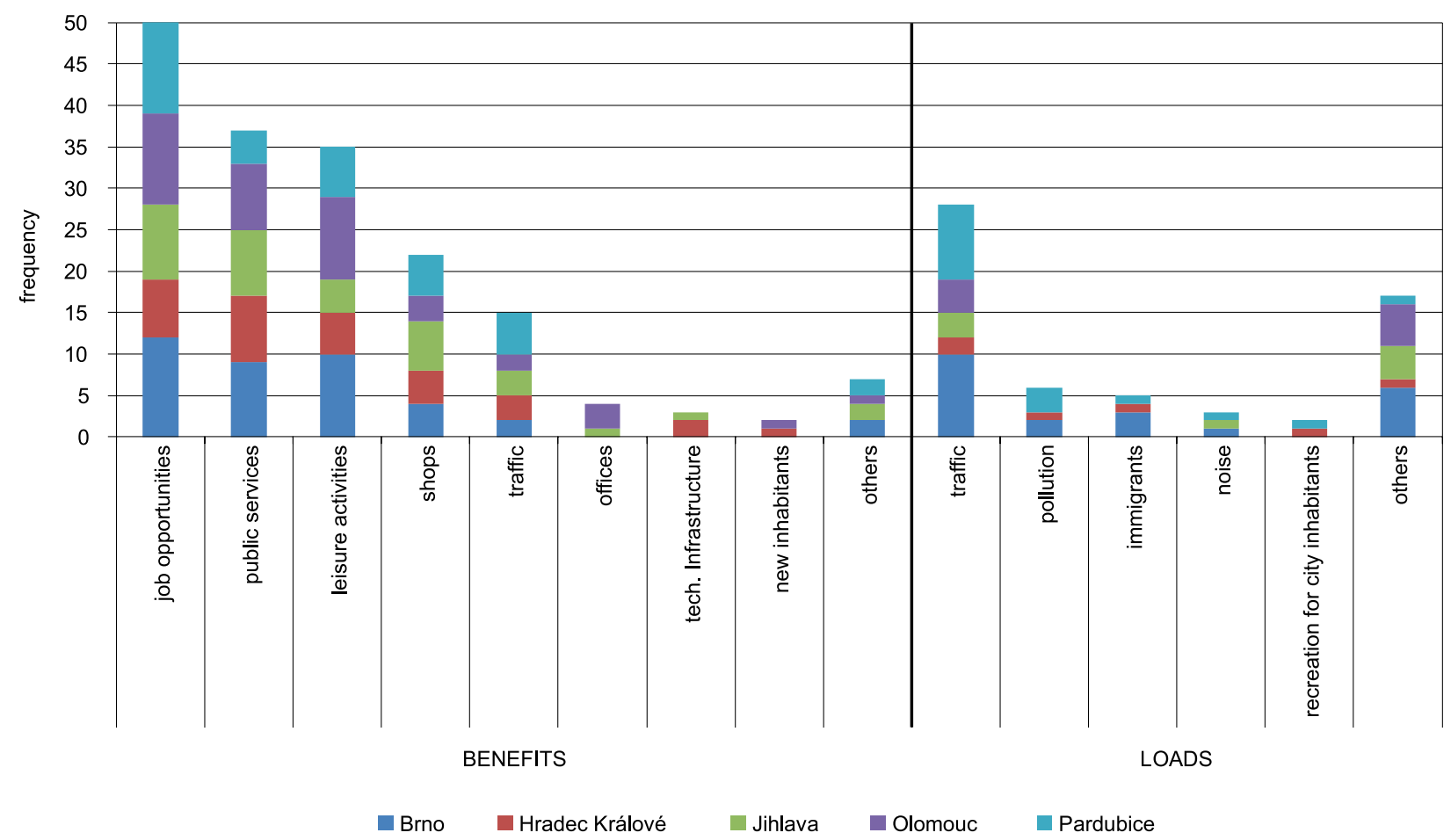

Fig. 2. Benefits and burdens of the large cities proximity for the municipalities in their hinterland. Source: Survey of 69 municipalities in the hinterland of the selected core cities, GaREP, 2014. 


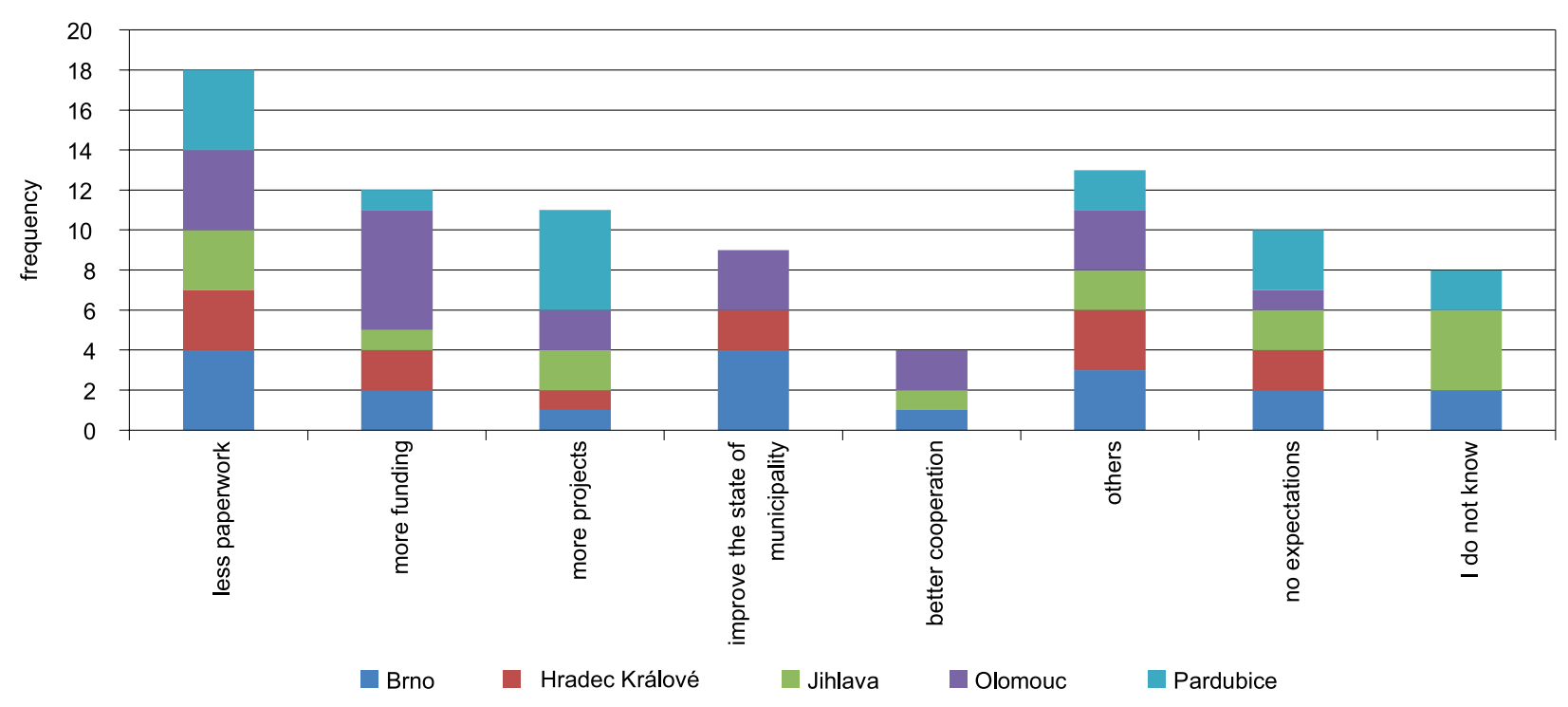

Fig. 3. Expectations of municipalities in the hinterland associated with the 2014-2020 programming period. Source: Survey of 69 municipalities in the hinterland of the selected core cities, GaREP, 2014

the projects for themselves. On the contrary, they worry about, e.g., their negative effects on the environment. Unwillingness to cooperate is then supported by bad experience with projects and their implementation in the previous programming periods (very demanding administration, complicated tenders, debts of municipalities, etc.). As a result, a number of municipalities have no expectations in connection with the start of the new period.

Another issue which the participants had to deal with is an unclear situation in the preparation of integrated approaches (e.g. the continual adjustment of methodologies, unclear financial allocation). Cities also feel the absence of areas of activity that they think they might develop especially tourism. The most painful problem is

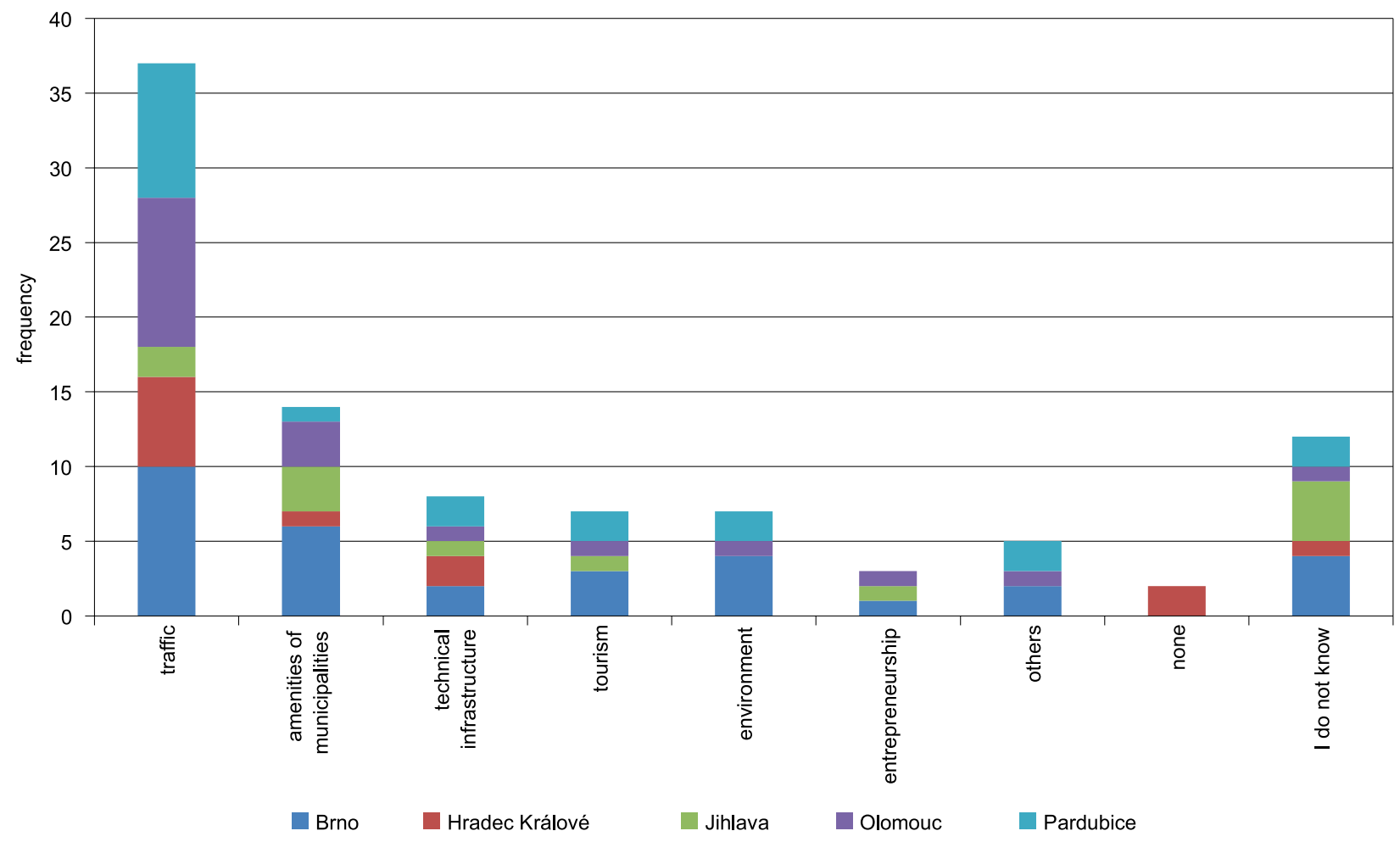

Fig. 4. The themes of the municipal projects that the municipalities would like to include in the ITI/IADP. Source: Survey of 69 municipalities in the hinterland of the selected core cities, GaREP, 2014 
the lack of legislation on broader cooperation of municipalities in agglomerations, an unclear responsibility of strategy operators for achieving the intended objectives, or penalties for an incorrect implementation of projects. Will the risk be distributed among the partners, or will the strategy operator be responsible?

Both the core cities and especially their environs are still waiting, despite many obscurities, for the beginning of a dialogue on major development issues. The process of preparing ITI/ IADP documents, most of which were prepared under the pressure of time due to an early start of the grant-awarding Operational Programme of Technical Assistance (OPTA), did not contribute to the development of good communication and mutual relationships either. Municipalities would like to deal with the following problem areas: co-financing of public transport, an integrated transport system, bicycle paths, allocating posts in nursery schools, adequate growth of the municipalities in the hinterland, property settlement, etc. Multi-fund co-financing of some of these topics will be possible from the European Structural and Investment Funds (ESIF): the Integrated Regional Operational Programme, the Transport Operational Programme, the Environment Operational Programme, the Enterprise and Innovation for Competitiveness Operational Programme, the Research, Development and Education Operational Programme, and the Employment Operational Programme. The multiple sources of financing and the involvement of various actors should ensure a real integrated territorial approach to the cohesion policy.

\section{Conclusions and recommendations}

In the context of integrated approaches in the Czech Republic, it would be good to list a few significant issues. The setting of the new programming period shows only a small continuity with that of 2007-2013. This creates completely new tools and new mechanisms, and the space for learning from the past mistakes is not large. Completely new systems are being created (with their own weak points) instead of innovations and removing the previous problems of the current structures.
Hypothesis $\mathrm{H} 1$ that foresees minimal cooperation between core cities and their hinterlands is confirmed by the results of the questionnaire survey. The core cities (i.e. agglomeration centres) and hinterlands cooperate minimally, it is usually bilateral and purpose-oriented cooperation (not comprehensive cooperation). The principles of an integrated approach are partially lost in generating complicated organisational structures. There are no mechanisms created for truly integrated projects. The projects with some characteristics are not considered for integrated projects but for ones that are included in an integrated strategy. However, only the implementation of ITI will show the real way and intensity of cooperation, and only in this way can hypothesis $\mathrm{H} 3$ be confirmed for sure.

Hypothesis $\mathrm{H} 2$ is also confirmed by answers of municipalities' representatives from the survey. The cities and mainly hinterland municipalities are not fully prepared to use the ITI, although the situation is improving. The implementation of the planned projects within the ITI includes with some exceptions - projects of the core cities.

We can conclude that the integrated approach is a useful tool supporting the integration and coordination of various subjects and the development of agglomerations. A truly integrated approach is not possible because of the question of financial support. Only partial areas are supported, and a truly comprehensive solution is hard to achieve. From the very beginning, a relatively complicated and multi-level system has been building, which looks quite logical at first glance, but at a second glance its functionality raises doubts. The challenge is how to coordinate individual actors within the ITI and to create an appropriate system of cooperation between its recipients and the managing authorities of the operational programmes.

\section{References}

Agietta M., 1979. A theory of capitalist regulation. New Left Books, London.

Blažek J., 1993. Regionální vývoj a regionální politika: hlavní přístupy v zemích západní Evropy (Regional development and regional policy: the main approaches in western Europe). In: Sýkora L. (ed.), Teoretické prístupy a vybrané problémy v současné geografii, Praha: 120-146.

Blažek J., 1996. Meziregionální rozdíly v České republice $\mathrm{v}$ transformačním období (Inter-Regional disparities in 
the Czech Republic during the transition). Geografie-Sborník ČGS, 101 (4): 265-277.

Blažek J., Uhlíř D. 2011. Teorie regionálního rozvoje, nástin, kritika, implikace (Theories of regional development, outline, criticism, implications). 2nd edition, revised and expanded. Karolinum. Praha.

Bagnasco A., 1977. Tre Italie. La Problematica Territoriale dello Sviluppo Italiano. Il Mulino, Bologna.

Becattini G., 1978. The development of light industry in Tuscany: An interpretation. Economic Notes 2 (3): 107-123.

Boudeville J.R., 1966. Problems of Regional Economic Planning. Edinburgh. University Press, Edinburgh.

Brusco S., 1982. The Emilian model: productive decentralisation and social integration. Cambridge Journal of Economics 6 (2): 167-184

Cooke P. (ed.), 1989a. Localities: The Changing Face of Urban Britain. Unwin Hyman, London.

Fujita M., Krugman P., 2004. The new economic geography: Past, present and the future. Papers in Regional Science 83 (1): 139-164. DOI: 10.1007/s10110-003-0180-0.

Holland S., 1976. Capital versus the Regions. Macmillan, London.

Christaller W., 1966. Central Places in Southern Germany. Englewood Cliffs. Prentice-Hall.

Integrated Territorial Investments - Europa, 2014. Online: http://ec.europa.eu/regional_policy/sources/docgener/informat/2014/iti_en.pdf (accessed 23 February 2016).

Isard W., 1960. Methods of Regional Analysis: An Introduction to Regional Science. The M.I.T. Press, Cambridge, Massachusetts.

Krugman P., 1991. Geography and Trade. The MIT Press, Cambridge, Massachusetts.

Krugman P., 1994. Complex landscapes in economic geography. American Economic Review 84 (2): 412-416.

Lipietz A., 1986. New tendencies in the international division of labour: regimes of accumulation and modes of regulation. In: Scott A., Stroper M. (eds), Production, Work and Territory: The Geographical Anatomy of Industrial Capitalism. Allen and Unwin, Boston and London: 16-40.

Lösch A., 1944. Die Räumliche Ordnung der Wirstschaft. Jena. (Engl. 1954 - The Economics of Location, Yale University Press, New Haven).

Markusen A.R., 1985. Profit Cycles, Oligopoly and Regional Development. The MIT Press, Cambridge, Massachusetts.

Martin R., 1999. Critical survey. The new "geographical turn" in economics: some critical reflections. Cambridge Journal of Economics 23 (1): 65-91.
Myrdal G., 1957. Economic Theory and Under-developed Regions. London, Gerald Duckwords.

Nelson R., 1988. The Agenda for Growth Theory: A Different Point of View. Cambridge Journal of Economics 22 (4): 497-520.

Ottaviano G.I.P., Thiesse J.F., 2005. New economic geography: what about the N? Environment and Planning A 37 (10): 1707-1725.

Partnership Agreement Austria, 2013.

Partnership Agreement Germany, 2014.

Partnership Agreement Ireland, 2014.

Partnership Agreement Poland, 2014.

Partnership Agreement Slovakia, 2014.

Partnership Agreement Slovenia, 2014.

Partnership Agreement Spain, 2014.

Partnership Agreement United Kingdom 2014.

Perroux F., 1950. Economics Space: Theory and Applications. The Quarterly Journal of Economics 64 (2): 89-104. DOI: $10.2307 / 1881960$.

Richardson H.W., 1979. Regional and Urban Economics. Pitman, Toronto.

Sheppard E., 2001. How "economists" think: about geography, for example. Journal of Economic Geography 1 (1): 131-136.

Schoenberger E., 1989. New models of regional change. In: Peet R., Thrift N. (eds), New models in geography. Unwin Hyman, London: 115-141.

Von Thünen J.H., 1826. Der Isolierte Staat in Beziehung auf Landschaft und Nationalökonomie. (English translation by C. M. Wartenberg: von Thünen's Isolated State, Oxford: Pergamon Press, 1966).

Vernon R., 1966. International Investment and International Trade in the Product Cycle. Quarterly Journal of Economics 80 (2): 190-207. DOI: $10.2307 / 1880689$.

Weber A., 1928. Theory of the Location of Industries, trans. C.J. Friedrich, University of Chicago Press, Chicago (originally published in German in 1904).

Wokoun R., Malinovský J., Damborský M., Blažek J., et al. 2008. Regionální rozvoj - východiska regionálního rozvoje, regionální politika, teorie, strategie a programování (Regional development - starting regional development, regional policy, theory, strategy and programming). Linde, Praha.

Wolpert J., 1970. Departures from the usual environment in location analysis. Annals of the Association of American Geographers, 60 (2): 220-229. DOI: 10.1111/j.1467-8306.1970. tb00717.x. 